\title{
Seafloor slime
}

\section{Alexis Templeton, Hubert Staudigel, Brad Tebo and colleagues ate tremendous amounts of papaya in a competitive manner while sampling seafloor rocks near Hawaii.}

\begin{abstract}
What was the original objective of the work?

The first time we went to Loihi seamount, Hawaii, we collected seafloor rocks with the intention of cultivating iron- and manganese-oxidizing bacteria that use seafloor basalt as their primary energy source for growth. Iron-oxidizing bacteria had recently been isolated from hydrothermal vents inside Loihi, but no one had yet explored whether they were prevalent on the rock surfaces that form the outer flanks of this underwater mountain. In many ways we are still actively exploring this question, in collaboration with many laboratories that are part of the Iron Microbial Observatory (FeMO) at Loihi seamount. However, as we examined the association between the iron and manganese oxide minerals and the biofilms coating the basalt surfaces we had collected, we began to question whether the mineral crusts represented the products of microbial basalt dissolution, or were instead deposited onto the rocks from sea water.
\end{abstract}

Why did you choose this particular location for the fieldwork?

Loihi was an excellent site for this project because it is an active submarine volcano close to major US ports, and has been well studied by Pisces submersible dives from the Hawaii Undersea Research Laboratory. The last significant volcanic episode occurred in 1996, and the seamount is seismically active and displays numerous hydrothermal vents that tend to be dominated by iron-rich fluids. These vents provide an exciting opportunity to explore geochemical and microbiological processes that differ markedly from the well known sulphur-dominated systems on many mid-ocean ridges.

What sorts of samples were you after? Our goal was to collect rocks from as many sites as possible on the outer flanks of the seamount, where the ambient temperatures are around $2{ }^{\circ} \mathrm{C}$. We spread the sampling out over three cruises in the past

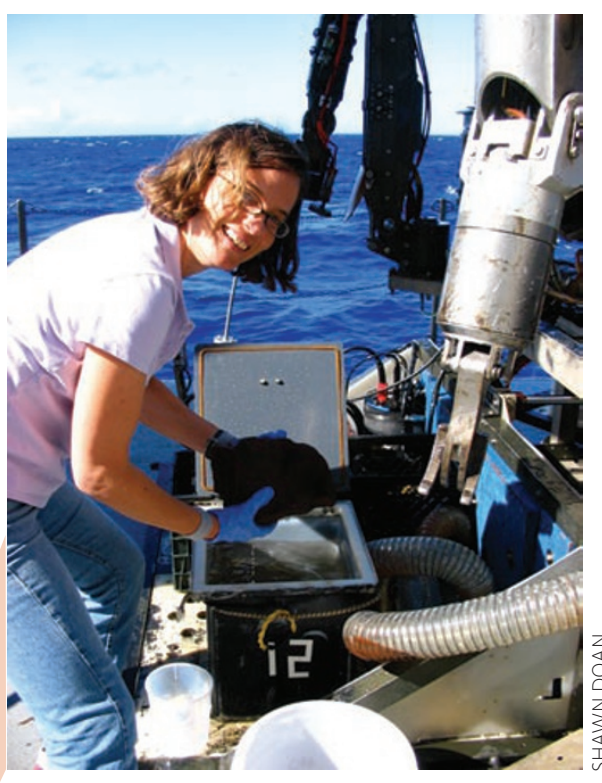

Alexis Templeton retrieving a seafloor basalt from the Jason II remotely operated vehicle.

six years; during this time we examined the seamount summit, breach, and northern and southern rift zones.

\section{Did you encounter any difficulties?}

We had to return to the same sites year after year to collect new rocks, or recover seafloor experiments. However, one of our favourite sites - Marker 17 at $\sim 1,700 \mathrm{~m}$ depth - disappeared; it was probably obliterated by a landslide. After numerous searches it became clear that we were not going to be able to collect our experiments from this site, which made it difficult to compare the rates of iron and manganese crust formation across the seamount. We have since encountered similar problems at some of the hydrothermal sites in Pele's Pit, the collapsed summit at Loihi, where experiments have been buried during vigorous venting. It seems that Pele, the Hawaiian goddess of the volcano, requires a sacrifice from the bounty of our scientific results!

Were there challenges in conducting the analytical work?

One of the most challenging aspects of the follow-up work was keeping track of all of the different types of microbiological and geochemical analyses conducted on each sample, especially because we shared each rock with several laboratories. But perhaps the most demanding aspect of the work was seeing how long we could each run on coffee and chocolate while conducting several days of round-the-clock analyses at the Synchrotron.

Did you learn anything new about your team members?

It's all about the food. Every time we were at sea, we had an informal competition to see who could eat the most and sweetest papayas on the ship, or when we were on shore, who could eat the most Hawaiian poke (the Hawaiian version of marinated raw fish). We also learnt that you become very unpopular if you bring tuna-fish sandwiches for your lunch in the submersible. The pilots consider it torture to be cooped up with the (dead-fish) smell for nine hours.

What was the highlight of the project? The excitement ran high on every dive at Loihi, and the excitement reached an even higher pitch the first time we devised a method to make an iron oxidation-state map for one of the rock surfaces. When we repeated the result on several rocks, we knew that our initial hypotheses regarding the geochemistry and geomicrobiology of the altered rocks needed to be reassessed.

Did your work give you any ideas for future research projects?

Yes! Some of our team have just returned from an FeMO cruise to Loihi, where they began the process of littering the seamount with new substrates that can help us record the rate of iron and manganese accumulation and biomineralization. We hope to deploy similar substrates at many sites of interest on the sea floor (including the East Pacific Rise, Juan de Fuca ridge, Guyamas basin and the Vailulu'u seamount) in the years to come, to work out how the rates of iron-manganese biofilm formation vary across the Pacific Ocean.

This is the Backstory to the work by Alexis Templeton and colleagues, published on page 872 of this issue. 